\title{
研究室紹介 \\ 酪農学園大学 農食環境学群 食と健康学類 食品物性学研究室
}

金田 勇*

(原稿受理：2019 年 10 月 1 日)

\section{1. 沿 革}

1988 年に日本で初めて「食品科学科」という名称の学科 が酪農学園大学に設置された。この新設学科立ち上げに尽力 された鮫島邦彦先生（酪農学園大学名誉教授: 肉製品製造学 研究室）の回想記によれば文部省（当時）の担当官から「食 品科学とはなにか？そんな学問があるのか？」と何度も尋 ねられたとのことである。今から考えれば隔世の感がある。 この新設学科に「食品物性学」という学科目が開講された。 この学科目が開講された経緯も伝聞ではあるが鮫島先生が食 品の物性研究および教育が重要であるとの考えによるもので あったらしい. 大変な先見の明と思われる。この食品物性学 を担当したのが当時北大理学部 (高分子学科) に所属してい た中村邦男先生であった。 その後 1996 年に「食品物性学研 究室」が新設されて, 学科目を非常勤で担当していた中村邦 男先生が北大から酪農大に異動されて研究室を担当された. 中村邦男先生が 2007 年 3 月に定年退職されたのちに金田が 中村邦男先生の後を引き継いで研究室を担当して現在に至っ ている.

2011 年に改組があり酪農学部食品科学科から農食環境学 群食と健康学類となったが, 食品物性学研究室はそのまま存 続している。 2019 年度現在のスタッフは金田勇 (教授) と 佐々木志帆 (嘱託助手) の 2 名で 4 年生 7 名 3 年生 6 名およ び大学院研究生 1 名というメンバーで構成されている.

研究テーマは中村邦男教授時代から食品のレオロジーに関 するものが中心であり, 筆者が引き継いでからはコロイド科 学的な観点からも研究を展開している. 以下に研究内容を簡 単に紹介したい.

\section{2. 研究内容の紹介}

\section{1）多糖類溶液・ゲルの物性}

筆者は長年化粧品メーカーにおいて化粧品原料としての高 分子素材の研究を担当してきたが, 食品物性学研究を担当す ることになり，まずは化粧品研究との類似性から食品の食感 （テクスチャー）の定量化および特徵的な食感を発現する食 品素材に関する研究に着手した。化粧品原料は食品原料を流 用したものが多く, まずはそれらの素材の基礎的な物性研究 を学生諸君と始めたのである. 研究材料は水溶性多糖類, 具

\footnotetext{
* 个 069-8501 北海道江別市文京台緑町 582
}

E-mail : kaneda-i@rakuno.ac.jp
体的にはサクシノグリカンおよび寒天に着目して研究を進め てきた。

サクシノグリカンとは微生物由来の細胞外多糖類であり高 い増粘効果に加え耐塩・耐酸性があるので高塩濃度食品や低 $\mathrm{pH}$ 食品のテクスチャー調整剤として活用が期待される素材 である。またこの多糖は水中で剛直な構造（二重らせん）を とるがそれが高温で解離して 1 本鎖の半屈曲鎖に転移する ${ }^{1)}$. これを冷却すると分子間相互作用が復活してらせん構造を再 形成しながら分子会合体を形成すると考えられているが2,3) その詳細は不明な点が多く興味深い多糖である。一方で寒天 は日本では古くから食べられてきた海藻由来の中性多糖類で あり，ローセットゲルを形成する。著者は寒天ゲルを「ソフ 卜な多孔性物質」とみなして寒天ゲルからの溶媒輸送挙動が 応力拡散結合理論で説明できることを明らかにしてきた ${ }^{4-6)}$.

しかしながらこれらの研究テーマは「食品の勉強をした い!」というモチベーションで入学してくる学生諸君にはあ まり人気のない研究テーマと言わざるを得ない面があった。 そこですこしずつ「芸風」を変える努力をしてきた，以下に 最近取り組んでいる研究を紹介する.

\section{2) Molecular-Physical Gastronomy（分子·物理的美食学）}

人間は「より美味しいもの」を求めるために知恵を絞って きた。現在我々が楽しんでいる美味しい食べ物のほとんどは 偶然に観察された現象とそれを経験的方法により再現性良く 調理されたものであると考えられる。すなわち調理とは長年 の経験に基づいた暗黙知の成果物であると考えられる。この 暗黙知を形式知化することで「美味しさ」の起源・原因を科 学的に解明し, 物理学的・分子論的に説明しょう, というの が分子・物理美食学の目的である7 . 具体的な食品に着目し て，それに関する疑問点を整理して，実験的にその謎を解い ていく, というスタイルで学生諸君と少しずつ取り組んでい る. 研究成果の一つとしてここでは手打ちうどんの非等方性 膨潤挙動について簡単に説明する ${ }^{8)}$. このテーマは「手打ち うどんはなぜエッジが立つのか？」という疑問から始まった． ここでいう「エッジ」とはうどんの麺線の稜の角度が鋭角に なった状態のことを指す。実験は手打ちうどんを打って，ゆ で上げる過程での麺線の断面の画像を取得しそれを解析する ことで「エッジ角」を定量化した。同時に麺線のヤング率測 定とうどんの原料である小麦粉に含まれるでんぷん粒とグル テン（たんぱく質）を染色した光学顕微鏡像を解析すること で手打ちうどんの展伸面と切断面で，でんぷん粒とグルテン の異方性があることが明らかになり，それがマクロに観察さ れる「エッジが立つ」という現象の原因であることを明らか 
にした。このほかにも現在進行中のテーマとしてメレンゲ (泡の物理学) や溶融チョコレート (濃厚固体分散体のレオ ロジー）を題材にした研究が進行中である.

\section{3）チーズのレオロジーとナノ構造}

非常に複雑であるがゆえにこれまで避けてきたチーズの研 究に昨年から取り組んでいる。このプロジェクトは本研究室 が主幹となり, 本学の乳製品製造学研究室の栃原孝志講師お よび北海道大学工学部量子ビーム工学分野の大沼正人教授と の共同プロジェクトとして研究を進めている。 チーズは数千 年の歴史のある食品であるが, 例えばチーズの構造を形成す るカゼインミセルの具体的な形態については現在でも論争中 である ${ }^{10)}$.またチーズ自体の特性についても科学的根拠を もって説明できていない課題が多く残されている。例えばピ ザに使われるモッッアレラチーズの曳糸性発現のメカニズム は完全には解明されていない" ${ }^{11)}$ 。本プロジェクトでは学内の 農場から原料乳を調達可能でチーズ製造時のさまざまな条件 をコントロール可能な酪農大でサンプル調製を行い, 本研究 室でのレオロジー研究（マクロな物性）と北大の X 線小角 散乱装置および直線加速器からの中性子線を利用したナノ構 造の解析の成果を合わせて考察することで, 北海道の主幹産 業である酪農業の生産物であるチーズを科学的に深く理解す ることを目的に研究を推進している。この共同プロジェクト をきっかけに「北海道食品レオロジー・構造相関研究コン ソーシアム」を立ち上げようと画策中である。

\section{3. おわりに}

流れるモノ・変形するモノはすべてレオロジー研究の対象 であるが, 食品の業界はレオロジー研究のパラダイスではな かろうかと感じている，面白いネタに事欠かないのである。 しかしながらこのような境地に達する前には 10 年ほどの時 間が必要であった。元々が理学部で専門教育を受けて育った ために食品のような複雑系（化粧品もだが.......) は考えるだ
けでも気が遠くなる存在であり, 真っ向から取り組むことを 避けていた。しかしながら複雑な食品をありのままで観察し， なんとか最小限の単純化をすることで実験をしてみることで, 意外に何とかなるものであるということに気づいたのがここ 数年である. 良い機会なので会員の皆様にお願いしたいこと がある. 理学・工学系の先生方に材料科学の観点から食品を 研究課題に取り上げていただきたい。そして討論会の食品の セッションでさまざまなバックグラウンドの先生方と議論し たいというのが老い先短い私の希望である。

\section{REFERENCES}

1) Kaneda I, Kobayashi A, Miyazawa K, Yanaki T, Polymer 43, 1301 (2002).

2) Kaneda I, Yanaki T, Koubunshi Ronbunshu 59, 8 (2002).

3) Kaneda I, Onodera Y, Nihon Reoroji Gakkaishi 37, 167 (2009).

4) Kaneda I, Iwasaki S, Rheologica Acta, 54, 437 (2015).

5) Kaneda, I, Sakurai Y, Food Hydrocolloids, 61, 148 (2016).

6) Kaneda I, Gels, 4, 23 (2018).

7) This H, Accounts of Chemical Research, 42, 575 (2009).

8) Kobayashi S, Kaneda I, Nihon Reoroji Gakkaishi, 46, 139 (2018).

9) Kaneda I, Miyazawa, H, Ito M, J. Rakuno Gakuen Univ., 39 1 (2014).

10) Ishii I, Milk Science, 54, 2 (2005).

11) For example; Lucey JA, Johnson ME, Horne DS, J. Dairy Sci., 86, 2725 (2003).

\section{当研究室の情報}

Facebook: https://www.facebook.com/foodrheo/

J-GLOBAL: https://jglobal.jst.go.jp/detail?JGLOBAL_ $\mathrm{ID}=201701015205508277$ 